\title{
Impasse and Opportunity: Reframing Postcolonial Territory at the India-Bangladesh Border
}

Jason Cons

\section{OpenEdition}

\section{Journals}

\section{Electronic version}

URL: http://journals.openedition.org/samaj/3791

DOI: 10.4000/samaj.3791

ISSN: $1960-6060$

\section{Publisher}

Association pour la recherche sur l'Asie du Sud (ARAS)

\section{Electronic reference}

Jason Cons, «Impasse and Opportunity: Reframing Postcolonial Territory at the India-Bangladesh Border », South Asia Multidisciplinary Academic Journal [Online], 10 | 2014, Online since 19 December 2014, connection on 01 May 2019. URL : http://journals.openedition.org/samaj/3791 ; DOI : 10.4000/ samaj.3791

This text was automatically generated on 1 May 2019.

\section{$(1) \Theta \Theta$}

This work is licensed under a Creative Commons Attribution-NonCommercial-NoDerivatives 4.0 International License. 


\title{
Impasse and Opportunity: Reframing Postcolonial Territory at the India- Bangladesh Border
}

\author{
Jason Cons
}

1 On 18 December 2013, the Congress Government introduced a bill in the Indian Parliament to implement the 1974 Land Boundary Agreement (LBA) with Bangladesh. ${ }^{1}$ If ratified, the Agreement would finally 'resolve' a border dispute that has long troubled India-Bangladesh relations concerning the presence of Indian enclaves in Bangladesh and Bangladeshi enclaves in India. Specifically, the LBA made way for the absorption of several hundred enclaves, chhitmahal in Bengali, into their bounding states. ${ }^{2}$ The bill was the latest in a long series of proposals to bring the enclaves into line with conventional understandings of territorial contiguity, sovereignty and national space. Like its predecessors, it faced long odds.

2 Enclave exchange has been a persistent and proverbial fly in the ointment of IndiaBangladesh border politics. This version of the bill proved no different. Members of the Bharatiya Janata Party (BJP) protested its introduction vociferously. Members of West Bengal's Trinamool Congress and the Asom Gana Parishad (Assam People's Party) attempted to physically arrest copies of the bill from India's external affairs minister ( The Times of India 2013). Trinamool MP, Derek O'Brian tweeted his disgust over the bill, writing, 'A lame duck government introduced Bangladesh Giveaway Bill' (DNA India 2013). Meanwhile, Mamata Banerjee, West Bengal's chief minister and head of the Trinamool Congress party, posted on her Facebook page, 'We are not accepting, not accepting and not accepting [the agreement]. The state government will not implement it' ( BDnews24.com 2013).

3 That the LBA seemed destined for failure was no surprise to those who have followed the enclaves' postcolonial diplomatic history. Yet, it did assert a series of urgent questions about the regional concept of South Asia and the territorial boundaries that constitute it. Postcolonial territory in South Asia-by which I mean both nationalist and communal 
ideologies of blood and soil and the specific claims and technologies for controlling space -presents a range of challenges and paradoxes to scholarly and popular imaginations of the region. ${ }^{3}$ This essay engages one of these challenges-enclaves-in order to make a series of claims about the salience of borders and border conflicts to postcolonial territory. As I argue at length elsewhere (Cons n.d.), these spaces are key sites in the production of postcolonial territory. They are 'sensitive spaces' that provoke anxious regulations and debates. By calling these enclaves 'sensitive' spaces, I mean that they trouble conceptualizations of state, nation, and citizen even as they are caught up in nationalist debates over security, sovereignty, and identity. The chhitmahal emerge not just as material sites, but also as issues within national politics that seem disproportionate to their size, population, or geopolitical import. They are thus productive places to begin disentangling the relationality between nationalist framings of territory and its quotidian experiences. Moreover, they have critical relevance for understandings-both political and scholarly-of South Asia.

4 The notion of South Asia as a region is predicated on a cartographic imagination of discretely cordoned-off states. As Ludden argues, 'Habits of mapping expunge dissonance from our geographical imagination by invisibly burying disorderly spaces under neat graphics of national order' (Ludden 2003: 1058). This Westphalian vision of orderly space constitutes a powerful mental map, one that governs not just scholarly inquiry, but political conceptualizations of space (Migdal 2010). ${ }^{4}$ Yet, within the region, not only has this orderly spatial imagination been a historical fiction, the disjuncture between it and ground realities has been a constant source of discord in nationalist politics and interregional relations-discord which has produced regular violence at and within national borders. ${ }^{5}$ These tensions suggest a need not just to better understand broad imaginations of territory or local experiences of it. They also suggest a need to attend to the relationships between these broad and localized framings-their articulations and disarticulations, their conjunctures and disjunctures. To do so implies thinking postcolonial territory as an analytic, rather than merely descriptive, category (Elden 2013, Sassen 2013).

5 The enclaves embody a telling impasse that haunts postcolonial territory in South Asianamely, the inability to disentangle material needs and realities of people living on the bleeding edge of state space from nationalist imaginations of blood and soil that are often indexed to the unfinished processes of Partition (Zamindar 2007, Chatterji 1999). To move beyond this impasse requires understanding the ways in which places such as the chhitmahal are amplified into sensitive space and the ways that people living in such spaces negotiate such amplifications. The enclaves demonstrate the limits to thinking of territory as only a political technology of rule-a set of practices organized around the ordering and management of space (Elden 2013). They are also emblematic of what Sanakran Krishna (1994) calls 'cartographic anxieties'-violent mappings of national anxieties of survival onto places like borderlands. At the same time, understanding these zones only through the lens of regulation or cartographic anxiety yields a vision of territory as effectively structured by national concerns. This belies lived realities in the enclaves and in South Asian borderlands more broadly, which are anything but passive reflections or imprints of national logics (essays in Gellner 2013). Territory, as much recent work has shown, emerges and is produced through both broad political maneuvering and more everyday forms of territory making (Erazo 2013). These local 
realities have a different story to tell about how territory is made and lived at the interstices of South Asia.

What I intend in this essay is to make a modest epistemological intervention into the discussion of borders, territory, and the concept of South Asia. Studies of borders often either choose to engage the broad, macro historical processes of border and state making, or the micropolitics of life in the shadow of state control. I propose that if we are to reimagine territory and region, both perspectives are necessary. Thinking these positions together at once exposes the mystifications of territory in nationalist debate and untangles the impasse of viewing space through a nationalist lens by bringing mobility, spatial regulation, violence, and competing territorialities within a single analytic frame (Sur 2014). ${ }^{6}$ My argument here is that to simply reject nationalist framings of space is to misunderstand the very processes that make spaces like the enclaves such intractable issues. Yet, to view the enclaves solely through such framings is to miss the idea that people living in sensitive space engage territory in ways not explainable solely within state or nationalist logics (Jones 2012b). What is important, then, is to understand the relationality between these two registers of territory and, moreover, to be attentive to this relationality's fluctuating dynamics. Such attention destabilizes uniform conceptualizations of territory and region in favor of more fluid and negotiated visions. Here, the region emerges as a tension between projects seeking to codify space along nationalist and often communal lines and a set of lived relationships and mobilities with contingent and unstable ties to such projects.

7 To illustrate this, I first look at debates over enclave exchange. These debates are characterized by persistent breakdowns of attempts to forge durable solutions to questions of territory and citizenship for enclave residents. Yet, if these negotiations have failed to yield exchange, we should not be misled into thinking that they have not been productive of territory. Indeed, national debates have produced the enclaves as particular kinds of spaces. This nationalist view of space does not constitute the only possibility for imaging borders and territory. A bottom up view produces a fundamentally different picture. I accordingly contrast the geopolitical history of the chhitmahal with a brief look at the lived experiences of one enclave, Dahagram, that has been at the heart of debates about the LBA. Not surprisingly, such a view yields a markedly different picture of life and space at the border. Yet, what I am more interested in are the ways that quotidian negotiations of projects of rule-often for purposes as straightforward as economic gain-highlight new forms of territoriality at the border. What emerges is not a rejection of official projects of control, but a transformation of them. This suggests the need and possibility for re-constituting the region from the margins by taking a more fluid and ethnographic vantage point (Van Schendel 2002a).

\section{Territory's 'odd-bits'}

8 What did the LBA contain that made it so objectionable to parties as dissimilar as the BJP and the Trinamool Congress? Why do these tiny blips of territory provoke such animated responses? One way to answer these questions would be to take the rhetoric of the current debate over the LBA seriously. A point that regularly emerges here is the disparity in the amount of land to be exchanged. ${ }^{7}$ The configuration of the enclaves to be swapped is such that there would be a net loss to India of approximately 10,000 acres, roughly .001\% of the country's total territory. Yet, as Das and Raju (2012) point out, this 
10,000 acres is land that Indian officials can neither access nor administer, as it falls on the wrong side of the international border with Bangladesh. It is only nominally part of India. Moreover, the land differential is so comparatively small that this concern might justifiably be read as a petty calculus of exchange. ${ }^{8} \mathrm{~A}$ more salient point raised in contemporary debates is the articulation of national policies towards the IndiaBangladesh border and the complex border politics within states along it. Controversies over the LBA within these states are indexed to long histories and concerns over crossborder migration, regional violence, and local autonomy in India's Northeast (Sur 2012, Chatterji 2007, McDuie-Ra 2012). Such concerns are clearly urgent and crucial in parsing the contemporary debate over the LBA. Yet, to see the conflict as a clash between national and regional politics, or as a squabble over small amounts of land, obscures the problematic place of the enclaves within counterpoised Indian and Bangladeshi national imaginations.

Rather, to understand the concern over such spaces, we must locate them within broader histories of territory and region. The chhitmahal were originally discontinuous territorial holdings of Zamindars and chieftains in the Mughal army's Northern incursion into the kingdom of Koch Behar (Van Schendel 2002b). At Partition, a number of chhitmahal found themselves on either side of a new border. As tensions between India and Pakistan escalated in the 1950s, there were increasing numbers of incidents related to these spaces (Whyte 2002). Yet, these conflicts remained largely matters of local negotiation between populations (both inside and outside of the enclaves) and government officials struggling with the complexities of the new Partition boundary. With the emergence of national debates over exchange, however, the enclaves began their transformation from one of a series of spatial problems into sensitive spaces-impossibly marginalized, yet increasingly central to national imaginations of territory.

The first attempt to address these troublesome spaces through exchange, thus normalizing the territorial complexities of the Bengal border, was the Nehru-Noon Accords. They reflected a decidedly optimistic technocratic perspective on territory-one that imagined that border issues could be resolved with a stroke of a pen. On 4 June 1958, in a somewhat cavalier statement made in his monthly press conference, Jawaharlal Nehru claimed that the ongoing border disputes between India and Pakistan were relatively minor and that 'any two reasonable people on behalf of the two Governments could sit together and decide them in a day or two'. ${ }^{9}$ This 'responsible' counterpart presented himself in Feroz Khan Noon, who assumed the Prime Ministership of Pakistan in December 1957. In early September, the two heads of state met in Delhi to hammer out the contours of just such an agreement.

In a triumphant 1958 Statement to the Lok Sabha outlining the results of the Accords, Nehru offered an account of the enclaves as minor abnormalities easily addressed through rational intervention:

The Cooch-Behar State had little bits of territory all over, and some of those fell in Pakistan and some in India on partition. [...] Therefore, the result is that we have some territory in Pakistan, little enclaves, little islands, and they have some here, which is very awkward. [...] They are just odd bits, usually the home of smugglers and other fugitives from the law. So, it has been decided ultimately that we should just exchange them.

Nehru's remarks reduced the enclaves to administrative hassles-odd 'bits' that could be managed through rational intervention. The enclaves are presented as territorial 
accidents-the result of Radcliffe's careless division of Bengal. The Accords would bring these problematic spaces in line with the map, with territorial norms, and, consequently, with the forces of law and order (Neocleous 2003). However, Nehru radically underestimated the enclaves' emerging resonance in nationalist discourse.

Almost immediately following the September $10^{\text {th }}$ announcement of the Accords, both Nehru and Noon were attacked by conservative oppositional parties within their own countries for having betrayed national interests and national sovereignty. In Pakistan, Fazlur Rahman, a Muslim League representative in Parliament, mounted an attack on Noon for what he claimed was a blatant attempt to 'to hoodwink and mislead the people to hide the fact of the shameless surrender of Pakistan's vital interests at the alter of Bharati appeasement' (Dawn 1958). Meanwhile, in India, Nehru was attacked by Jana Sangh MP and future BJP Prime Minister Atal Bihari Vajpayee, who claimed that the Accords were not only illegal, but a betrayal of national interest and the rights of citizenship of Indian enclave residents. As Vajpayee argued, 'Nobody, not even the Prime Minister, has the right to deprive any Indian citizen of his nationality and citizenship'. By tying the question of territory together with citizenship, Vajpayee reframed the chhitmahal not just as zones filled with criminals and smugglers, but also as spaces within which Indian [Hindu] citizens clung to tenuous national territory. In short, the enclaves became territorial symbols-spaces encapsulating the antinomies of post-Partition belonging.

The Accords proved a political stumbling block for Nehru's Congress Party. In the face of increasing opposition, Nehru was forced to qualify his earlier enthusiasm in a statement to the Lok Sabha in 1960:

At the time I was clear in my mind that the whole agreement, in spite of certain aspects of it which were not agreeable to us, was profitable and advantageous. [...] But there is a 'but'. I did not realise then that there is a certain human aspect of it. [...] And subsequently when this aspect has come before me, I have felt troubled in my mind.

Nehru's suddenly 'troubled mind' underscored how deeply affective questions of territorial integrity can be in nationalist discourse (Billé 2013). ${ }^{10}$ It highlighted the stakes of not treating the enclaves 'sensitively'. In this regard, Nehru's reversal captures a central trope in the chhitmahal's postcolonial history-their seeming stubborn refusal to be resolved through well-intentioned policy and their persistent capacity to raise nationalist ire.

\section{Corridors of territory}

16 Following the Bangladesh Liberation War in 1971, Indira Gandhi and Sheik Mujibur Rahman attempted to capitalize on the goodwill between India and newly independent Bangladesh to resolve outstanding border issues between the two states. The results were the 1974 LBA, also known as the Indira-Mujib Accords, which proposed a wholesale exchange of the enclaves on either side of the border with one exception. Bangladesh was to relinquish its claim on a disputed border area known as Berubari. In exchange, India would lease, into perpetuity, a 170-meter long land bridge known as the Tin Bigha Corridor connecting Dahagram-Angarpota (henceforth Dahagram)-the largest Bangladeshi enclave situated in India-to 'mainland' Bangladesh. ${ }^{11}$ Once again, the Agreement prompted heated debate on both sides of the border over the legality and 
ethics of handing over territory to another sovereign state. Bangladesh soon ceded Berubari. However, the struggle to open the Tin Bigha Corridor was to become a morass of nationalist and increasingly communal politics.

In 1981, as a step towards resolving the question of Dahagram and pushing for implementation of the 1974 Treaty, the Government of Bangladesh attempted to conduct a census of the enclave. Terms of passage through Indian territory were negotiated for census workers, but following the implementation of the census, local activists in India organized a blockade of the enclave, cutting it off from access to both Indian markets in Mekhliganj and Bangladeshi markets in Patgram (for discussion, see Cons 2012). The Bangladesh Observer reported that supplies of food and medicine in the enclave were scarce and that several residents had died from starvation and lack of medical care. 'Equipped with guns, arrows, lathis and hand bombs, the Indian nationals are patrolling around these enclaves, preventing helpless Bangladeshi nationals of Dahagram and Angarpota to come out and enter Bangladesh main soil to purchase essential commodities'(Bhasin 1996: 808). The expression of outrage in the piece captured not just an offence committed against a marginal population at the border, but an offence against 'nationals'-beleaguered citizens who lived at the mercy of a territorially aggressive Indian state and population. It further flagged the question of enclave exchange as both symbolic and symptomatic of India's willingness to discount Bangladeshi lives and the rights of the Government of Bangladesh to protect them. As the Bangladesh Times wrote, 'an inherent and a legally vested right of a population and its natural custodian, the State of Bangladesh, is going ignored' (Bhasin 1996: 808).

The media coverage of the blockade in Bangladesh raised concerns in the Lok Sabha about its overall impact on India-Bangladesh relations. In a heated debate, Amar Roy Pradhan, an MP from West Bengal, dismissed concerns over the census, suggesting that the suffering of residents of Dahagram was inconsequential compared to the suffering of over 100,000 Indian citizens living in Indian enclaves inside of Bangladesh. In Pradhan's words, 'in Bangladesh, they are living under sub-human conditions-no administration, no police, no chowkidar, no panchayats, no voting, nothing of the sort. It is a matter of grave regret' (Bhasin 1996: 804). Pradhan's observation reflects not an empirical or demographic reality of life in Indian enclaves, but rather, a political imagination of territory, community, and suffering (Moore 2005). This and ensuing debates indexed the enclaves to broader concerns in the relationship between India and Bangladesh. These included the rights of citizens (of both states) at the border, the sovereign control of space, and the sanctioned violence (real and imagined) against those living on this contested edge of territory.

19 If the enclaves became a zone in which nationalist and often-communal politics were regularly grafted onto space, they also are sites in which moments of cross-border cooperation do, occasionally, produce change. Despite vociferous debate, the Tin Bigha Corridor finally opened on 26 June 1992 in a moment of diplomatic thaw following the removal of General Mohammed Ershad from power in Bangladesh (Cons 2012). The return of democracy to Bangladesh eased the politics of opening the Corridor, but not the nationalist rhetoric around it. It opened amidst the arrests of numerous local activists and threats by the BJP to train a 'suicide squad' to prevent its opening (Chaudhuri 1992). Initially, the Corridor was open for only one hour a day. This amount of time was gradually increased until, in 2002, it was opened for 12 hours a day, during daylight hours. If the LBA's partial fulfillment addressed some of the spatial challenges of 
Dahagram, however, it also further transformed it into a stage upon which territorial dramas were enacted (see below). Moreover, the Corridor transformed Dahagram into the most closely monitored chhitmahal along the border, surrounded by BSF watchtowers and regularly patrolled by armed paramilitary border guards from each country.

This episodic history signals the patterns that have shaped the debates over enclave exchange-patterns that have reappeared in the current round of negotiations regarding the LBA. It also points to ways in which territorial imaginations and cartographic anxieties become inextricably linked to territorial practicalities and attempts to resolve and rationalize space. Following Mitchell (2002), one might argue that territory here emerges as the mutual constitution of affective representation and reality-a particularly problematic and emotive enframing of space. Seen as such, the enclaves represent a territorial impasse-the inability to disentangle concrete space from the imagination of it as simultaneously threatening and under threat. Such an impasse does not, as we have seen, preclude meaningful transformation in border-politics. Indeed, attempts by political leaders to think past this impasse have lead to concrete changes in life at the border. But it does systematically efface other possible imaginations of territory and region. How might we think beyond this impasse? My suggestion here is that we begin by considering the spatial imaginations and negotiations of those who live in the enclaves themselves.

\section{Quotidian forms of territory}

21 If part of the project of rethinking South Asia is imagining possibilities as well as limitations, it is important to also examine the ways that territory might be rethought from a more grounded perspective. The articulation between the enclaves as imagined and concrete spaces has crucial implications for the lives of those living there. Indeed, the outcomes of the broad debate over Dahagram and the Tin Bigha Corridor have been central features of life in the enclave. Yet, at the same time, life in Dahagram is shaped by more than these framings alone. It is a fluid negotiation of a range of processes that converge in sensitive space. To conclude, let me then focus on a set of recent transformations in Dahagram's political economy in order to highlight the ways in which broad imaginations and negotiations over territory refract in particular spaces. ${ }^{12}$

In 2007, when I began conducting research in the enclaves, Dahagram was a palpably uncomfortable place. Tensions over the Corridor were high and disagreements between India and Bangladesh (and between Congress and the Bangladesh National Party) were escalating-particularly in conjunction with the building of the border fence with Bangladesh and with the regular shooting of Bangladeshis by BSF troops at the border (see Jones 2012a, Human Rights Watch 2010, Sur 2014). Meanwhile, numerous development initiatives were at work within the enclave. These had produced, among other things, paved roads that saw little or no use by motorized vehicles, a fully constructed functioning hospital that had never opened for business, and a model village project devoid of denizens. All of these projects seemingly demarcated and laid claim to the enclave as Bangladeshi territory, but had little impact on the well-being of the enclave's residents. Local transportation was limited to rickshaws and cycle-vans. To get to Dahagram, it took at minimum an hour ride from Patgram, the nearest market town in Bangladesh, approximately $11 \mathrm{~km}$ away. People were anxious about the future and, especially, about the Corridor, often suggesting that the BSF could close the Corridor for good on a whim. Such fears were supported by the BSF's occasional implementation of 
new restrictions on what could be brought through the Corridor, especially the number of cows that could be transported to market. ${ }^{13}$ Agriculture within the enclave was robust, with regular trade with Patgram, but there was little other industry or open commerce besides a few tea stalls and tailoring shops. In short, life in Dahagram seemed oppressively marked by broader tensions over the border and their corresponding politics and anxieties.

In 2013, I returned to Dahagram after several years, to discover a remarkably different set of circumstances. In my absence, the enclave had transformed into a frontier boom-town. Now, instead of rickshaws, I traveled to Dahagram via a regular tempo van. The two hubs of activity in the enclave-Guchogram near the Tin Bigha Corridor and Bongerbari, the administrative and political center of the enclave-were bustling and crowded not just with people but also hulking and brightly colored transportation trucks. There was a steady stream of traffic moving through the Corridor. Moreover, the atmosphere seemed to have shifted from one of anxiety to one of comparatively prosperous optimism.

The apparent reason for this transformation was the opening of the Tin Bigha Corridor for 24 hours a day on 19 October 2011. This opening, thus far, represented the only tangible outcome of the new debates over the LBA. The opening marked a significant moment in the history of the enclave. Now, while the Corridor remained under the administration and control of the BSF, enclave residents could come and go, day or night. Signaling the national significance of both the Corridor and of Dahagram, the opening was presided over by Prime Minister Sheik Hasina, the first visit by a head of state to Dahagram since before the opening of the Corridor in 1992. Hasina's visit to the enclave was recalled with pride by almost everyone I spoke to. A new brick and concrete memorial to her had been raised in the center of the enclave. During her visit, Hasina also granted a series of longstanding demands of enclave residents, noting, according to my informants, that 'these people have suffered enough. Give them what they ask for.' Enclave residents regularly expressed the feeling that they were now, truly, citizens of Bangladesh. As a smallholder farmer I spoke with had it, 'the opening of the Corridor for 24 hours has put us in a better frame of mind. Things are good here now.' On the surface, it appeared as though geopolitical negotiations over space at the border had, indeed, yielded positive transformations in the lives of border residents. Yet, even a cursory glance at what was happening in the enclave revealed that the Corridor's opening was not the only, or perhaps even the most significant, change in Dahagram's landscape. What appeared to be the more immediate source of the enclave's shift in fortunes was the massive adoption of a relatively new cash crop: corn. Every available plot of land seemed covered in corn husks and stalks from the recent harvest. A number of new godowns had been built since my last visit, all now bursting at the seams. The large trucks in the enclave were being stacked high with sacks of corn as well. Corn kernels were drying on many of Dahagram's paved roads, transforming the color of the tracks from a dull asphalt grey to a bright golden yellow.

The demand for corn was being driven by Bangladesh's thriving poultry and shrimp aquaculture industry. ${ }^{14}$ It had clearly emerged as a major boom crop in the Patgram region as a whole, not just in Dahagram. 'People are growing corn even in their courtyards,' a man in Patgram told me. Yet, its transformation of the enclave was especially stark. Its introduction, at scale, into the region began in 2007, when a company called Doyel, with funding and support from crop and soil scientists at Cornell University and CIMMYT, the International Maize and Wheat Improvement Center, had introduced 
the crop into Patgram (CIMMYT E-News 2009). They had done this by partnering with a national bank which offered a microcredit scheme whereby Doyel would hold the provisional land titles of farmers in Dahagram and guarantee loans for farmers to purchase seed stock. The scheme was launched in Dahagram in early 2007 at a ceremony that I attended, a ceremony that was, itself, framed as an intervention that honored Dahagram residents' long-history of suffering. As the NCC official who visited the enclave to launch the scheme made clear, the loans-for-corn-seed program was not framed as a strategy to expand agricultural markets, but rather as a gesture to honor the struggle for the enclave and to help its downtrodden and marginalized residents. ${ }^{15}$

Doyel ultimately went out of business, and many in the enclave complained that the company never returned their land titles. Others complained that recalcitrant farmers in the enclave had forced Doyel out of business by failing to repay their loans. Whatever the reason for the company's failure, the gap opened by Doyel was a business opportunity for local groups within the enclave seeking to establish new modes of territorial control. After the enclave opened in 1992, as I describe elsewhere (Cons 2013), a flood of new migrants moved in and purchased land from Hindu residents, many of whom were abandoning the enclave, at fire sale prices. These new migrants were known locally as Bhatiyas (outsiders), and though they remained politically marginal within Dahagram, they quickly emerged as central economic players, expanding existing holdings and experimenting with new strategies for capital accumulation. Indeed, though Doyel's initial expansion into Dahagram was framed as a celebration of the enclave's history it was primarily Bhatiya farmers who began adopting the new crop.

Beginning in 2011, around the time that Doyel was collapsing and the Corridor was opened for a full 24 hours, several of these farmers banded together to capitalize on the possibilities of corn. This new syndicate began providing seed and fertilizer at preferential prices to farmers in Dahagram in exchange for purchasing rights to the harvested crop. This allowed them to develop a monopoly on corn exports from the enclave. Such arrangements are not uncommon in Bangladesh and are part and parcel of how many mohajan [moneylending] and syndicate operations work. Indeed, this one seemed particularly successful. One of the heads of the syndicate-a Bhatiya farmer who had risen from modest means to become one of the wealthiest denizens of the enclavetold me that $95 \%$ of all cultivatable land within the enclave was now being used for corn production. People seemed to be making money hand over fist.

Derek Hall (2011) argues that crop booms, such as the explosion of corn production in Dahagram, provide crucial clues to the ways that smallholders reconfigure land-rights and uses by bringing a range of different forms of power to bear on the control of land. Yet, the emergence of corn in Dahagram also spoke to the ways that broader political debates over territory transformed a range of productive possibilities in sensitive space. Members of the syndicate that I spoke to openly acknowledged that seed money from the venture came from the smuggling of household goods from India into the enclave for sale. Yet, other smallholder farmers in the enclave who were the syndicate's clients told a different origination story of the corn boom-that of cattle smuggling. Cattle smuggling has long been a central trope in debates over the India-Bangladesh border. The export has proved a profitable trade for both those involved in smuggling itself and border security forces who often become its de facto regulators. ${ }^{16}$ The trade is inflected by a communal rhetoric-the transportation of sacred cows over the border for slaughter in Muslim meat markets. 
30 When I began research in the enclave in 2007, a crackdown on smuggling through the enclave had emerged as the central political concern of both the BSF and of parties within Dahagram. Specifically, the BSF had placed a cattle ceiling on the movement of cows through the Corridor, limiting the number of cattle that could be taken to market to six on any given haat (market) day. The ceiling had been not only a source of tension, but also a mechanism for re-arranging political power within the enclave. The Union Parishad Chairman at the time, who many suggested was deeply implicated in cattle smuggling himself, was given the power to decide who within Dahagram would be allowed to take cattle to market. The Chairman immediately began using this as a tool to consolidate his own political power.

31 In 2013, the ceiling still remained in place, but its enforcement had become markedly lax. Yet, with the opening of the Corridor for 24 hours a day in 2011, and with the general ease in tension along the border that marked the joint tenure of the nominally amicable Congress Party and the Awami League, cattle smuggling had re-emerged as a major source of capital within the enclave. Not only had schemes for smuggling cattle through the Corridor re-surfaced, but a longstanding relationship with cattle smuggling rings in surrounding Indian areas had been revitalized with a mandated relaxation in border patrols in the area. Numerous farmers who I spoke with pointed to this reemergence in the cattle trade as the source of capital for launching the corn syndicate and transforming the enclave's agricultural landscape.

The political economic transformations related to Dahagram's corn boom were thus as intimately tied to shifts in the political imagination of the border as they were to concrete transformations in border policy and broader frameworks of capital accumulation within Bangladesh. The contingent convergence of a crop boom with a moment of comparative cross-border cooperation-a moment which also facilitated the opening of the Corridor for 24 hours a day-had produced a significant shift in the fortunes of Dahagram farmers. Such shifts, I would argue, suggest not a withering away or resolution of sensitive space. Rather, they indicate shifts in the relationality between broad nationalist and more localized registers and framings of territory. Creative individuals in such spaces make use of such shifts for material advantage, control of terrain, and remaking territory in ways that best suit their own ends. Yet, this relationality itself is highly unstable and subject to constant transformation. Indeed, the linkages between border politics, cattle, and corn suggest that Dahagram's corn boom may be a particularly ephemeral transformationone subject not just to market fluctuations, but also to the return to power of political parties, in either state, less disposed to cross-border cooperation. ${ }^{17}$

Importantly, neither the focus on nationalist representation nor lived realities alone can explain these recent transformations in Dahagram. On the one hand, viewed from the nationalist vantage point, Dahagram appears as a sensitive space-one that embodies the tension between administration of a challenging border and a range of nationalist anxieties over territory, identity, and the unfinished business of Partition. Understanding such a perspective helps in untangling the complexities of space in Dahagram-tensions over the movement of people and goods through the Corridor, the stakes and symbolics in the opening of the Corridor for 24 hours a day, and more. Yet, viewed from inside of the enclave, Dahagram appears as more of a vector for broader sets of territorial issuesthe political economy of Bangladesh, fluctuations in outlook towards smuggling, the politics of land use. Looking from these vantage points simultaneously opens up ways to 
see the articulations between national anxieties over the border and everyday habitations of it.

\section{Conclusion}

This essay makes an epistemological contribution to the re-imagination of postcolonial territory, a re-imagination that has implications for both analytic and political figurings of South Asia. A longstanding contention of border studies has been that the margins are productive locations from which to think nation, state, and territory (see Cons \& Sanyal 2013). This is so not just because margins are privileged locations for engaging the contradictions of state-making, but also because margins are often intimately bound up in conceptualizations and imaginations of nation and state. ${ }^{18}$ That said, many studies that engage this challenge take a bifurcated approach, focusing either on the ways that nations frame their borders, or on how local territorialities constitute alternative spatial modes. Paradoxically, in both narratives, state control of space continues to be the central dynamic and focus of analysis. My claim here is that to understand the vagaries of territory in postcolonial South Asia, we must incorporate both of these into a single analytic frame in ways that are attendant to the securitization of space, but not overdetermined by them. What we should attend to is the relationship between these two registers, the extent to which articulations do and do not emerge between them, and the ways that such articulations open up new possibilities-political, economic, and otherwise -for people who navigate borders on a daily basis. Such a project is not unique (see, for example, Jones 2012b, McDuie-Ra 2012). Yet, its implications continue to be critical in moving beyond monolithic and polarized views of territory and of South Asia as a region.

Analytically, an examination of the histories of sensitive space illustrates the way that territory emerges out of a confluence of deeply affective anxieties about the 'nation,' and its 'citizens.' Spaces such as the enclaves are over-represented in national imaginations of territory precisely because they unsettle territorialized national imaginations (Billé 2013). They are spaces that, to paraphrase Schmitt (1985) (paraphrasing Kierkegaard) the center thinks with intense passion. These spatial imaginations collectively produce what I call here a territorial impasse-the inability to disentangle spatial imaginaries from spatial practicalities. These cartographic anxieties are manifest not just in Parliamentary debate, but in the very landscape of spaces such as Dahagram. The maintenance of boundaries-dramatized in the politics of the Tin Bigha Corridor-is central to producing national territory and to shaping the lives of those who live in borderlands. Yet, life in the borderland is more than simply a product of national anxieties. It is better described as an engagement with the terrain that emerges from overlaps between nationalist and other processes that shape territory-for example, the strategic exploitation of crop booms and cattle smuggling. The relationship between these two perspectives yields a shifting and unstable picture-one of both radical disconnects, such as hospitals that serve no one, and moments of convergence, such as Dahagram's current corn boom. This picture has critical implications for our understanding of the production of territory. On the one hand, it troubles coherent narratives about the framing and control of space. On the other, it helps reframe territory as an active dialogue and set of negotiations over the meanings and uses of land, of borders, and of projects that seek to establish often contradictory forms of rule. 
Mrinalini Sinha, in a defense of regionalism, suggests, that "by the sheer ambiguity and elusiveness of its definition, [the regional] provides an opportunity to reflect more pointedly on the fact that all spatial boundaries are inherently political and contingent' (Sinha 2013:266). As I have argued in this essay, a possible starting point for reconstituting the regional notion of South Asia-to take, as Sinha urges, an 'angular' relationship to the nation-is to rethink territory from the perspective of both margins and centers. If an understanding of broad projects of territory-making yields a view of the ways territory is ossified in nationalist debate, a perspective from within sensitive space yields different possible understandings. Cartographic anxieties blend with and are transformed by geopolitical currents, political economic trends, and the quotidian ways that people in borderlands carve out livings against a landscape of political flux. South Asia emerges as a striated space-overlapped and crisscrossed by people who struggle to work around and past incomplete projects of spatial governance and intermittently ossified borders..$^{19}$ If my call to rethink the region this way is not unique, it is no less urgent against South Asia's contemporary landscape-a landscape in which, as debates over the LBA suggest, territory remains a fraught battleground in which affective nationalist imaginations of space efface the lived realities of places such as Dahagram.

\section{BIBLIOGRAPHY}

BDnews24.com (2013) 'Mamata's Furious Reaction', December 19, URL: http://bdnews24.com/ bangladesh/2013/12/19/mamata-s-furious-reaction.

BDnews24.com (2014) 'BJP Leader's Remarks on Bangladesh Flayed', April 19, URL: http:// bdnews24.com/world/2014/04/19/bjp-leaders-remarks-on-bangladesh-flayed.

Billé, Franck (2013) ‘Territorial Phantom Pains (and Other Cartographic Anxieties)', Environment and Planning D: Society and Space, 31(1), pp. 163-78.

Bhasin, Avtar Singh (ed.) (1996) India-Bangladesh Relations 1971-1994: Documents, Volume Two, Delhi: Siba Exim Pvt. Ltd.

Brenner, Neil (1999) 'Beyond State-Centrism? Space, Territoriality, and Geographical Scale in Globalization Studies', Theory and Society, 28, pp. 39-78.

Chatterji, Joya (1999) 'The Fashioning of a Frontier: The Radcliffe Line and Bengal's Border Landscape, 1947-52', Modern Asian Studies, 33 (1), pp. 185-242.

Chatterji, Joya (2007) The Spoils of Partition: Bengal and India, 1947-1967, New York: Cambridge University Press.

Chaudhuri, Kalyan (1992) ‘The Tin Bigha Link: A New Lease of Friendship’, Frontline, July 17.

Chitkara, M. G. (1997) 'De-Indianised Enclaves', in M.G. Chitkara (ed.), Bangladesh-Mujib to Hasina, New Delhi: APH Publishing Corp, pp. 120-28.

CIMMYT E-News (2009) 'Maize Motorizes the Economy in Bangladesh', 6(5). 
Cons, Jason (2012) 'Histories of Belonging(s): Narrating Territory, Possession, and Dispossession at the India-Bangladesh Border', Modern Asian Studies, 46(3), pp. 527-58.

Cons, Jason (2013) 'Narrating Boundaries: Framing and Contesting Suffering, Community, and Belonging in Enclaves along the India-Bangladesh Border', Political Geography, 35, pp. 37-46.

Cons, Jason (n.d.) Sensitive Space: Anxious Territory at the India-Bangladesh Border.

Cons, Jason and Romola Sanyal (2013) 'Geographies at the Margins: Borders in South Asia-An Introduction', Political Geography, 35, pp. 5-13.

Das, Rukmini and Deepak Raju (2013) 'A Settlement Long Overdue', The Hindu, August 13, URL: http://www.thehindu.com/opinion/lead/a-settlement-long-overdue/article5016349.ece.

Das, Veena \& Deborah Poole (eds.) (2004) Anthropology in the Margins of the State, New Delhi: Oxford University Press.

Dawn (1958) 'Border Accord is a Betrayal of Pakistan Interests', September 17.

DNA India (2013) ‘Bangladesh Boundary Agreement Bill Tabled in Rajya Sabha Amidst Protests', December 19, URL: http://www.dnaindia.com/india/report-bangladesh-boundary-agreementbill-tabled-in-rajya-sabha-amid-protests-1937559.

Elden, Stuart (2013) The Birth of Territory, Chicago: University of Chicago Press.

Erazo, Juliet (2013) Governing Indigenous Territories: Enacting Sovereignty in the Ecuadorian Amazon, Durham: Duke University Press.

Feldman, Shelley (2003) 'Bengali State and Nation Making: Partition and Displacement Revisited', International Social Sciences Journal, 175, pp. 113-21.

Garg, Ibu (2013) 'The India-Bangladesh Land Swap Deal', The Diplomat, September 3,URL: http:// thediplomat.com/2013/09/the-india-bangladesh-land-swap-deal/

Gellner, David (ed.) (2013) Borderland Lives in Northern South Asia, Durham: Duke University Press. Hall, Derek (2011) 'Land Grabs, Land Control, and Southeast Asian Crop Booms', Journal of Peasant Studies, 38(4), pp. 837-57.

Human Rights Watch (2010) 'Trigger Happy': Excessive Use of Force by Indian Troops at the Bangladesh Border, New York: Human Rights Watch.

Hussain, Delwar (2013) Boundaries Undermined: The Ruins of Progress on the India-Bangladesh Border, London: C. Hurst \& Co.

Ibrahim, Farhana (2009) Settlers, Saints, and Sovereigns: An Ethnography of State Formation in Western India, London: Routledge.

Jones, Reece (2009) 'Sovereignty \& Statelessness in the Border Encalves of India and Bangladesh', Political Geography, 28, pp. 373-81.

Jones, Reece (2012a) Border Walls: Security and the War on Terror in the United States, India, and Isreal, London: Zed Books.

Jones, Reece (2012b) 'Spaces of Refusal: Rethinking Sovereign Power and Resistance at the Border', Annals of the Association of American Geographeres, 102(3), pp. 685-99.

Krishna, Sankaran (1996) 'Cartographic Anxiety: Mapping the Body Politic in India,' in Michael Shapiro and Hayward Alker (eds.), Challenging Boundaries: Global Flows, Territorial Identities, Minneapolis: University of Minnesota Press, pp. 193-214. 
Ludden, David (2003) 'Presidential Address: Maps in the Mind and the Mobility of Asia', Journal of Asian Studies, 62(4), pp. 1057-78.

McDuie-Ra, Duncan (2012) 'Tribals, Migrants and Insurgents: Security and Insecurity along the India-Bangladesh Border', Global Change, Peace \& Security, 24(1), pp. 165-82.

Middleton, Townsend (Forthcoming) Terms of Difference: Tribal Recognition, Autonomy, and the Politics of the Ethno-Contemporary in India, Stanford: Stanford University Press.

Migdal, Joel (2010) 'Mental Maps and Virtual Checkpoints: Struggles to Construct and Maintain State and Social Boundaries' in Joel Migdal (ed.), Boundaries and Belonging: States and Societies in the Struggle to Shape Identities and Local Practices, Seattle: University of Washington Press.

Mitchell, Timothy (2002) Rule of Experts: Egypt, Techno-Politics, Modernity, Berkeley: University of California Press.

Moore, Donald (2005) Suffering for Territory: Race, Place, and Power in Zimbabwe, Durham: Duke University Press.

Neocleous, Mark (2003) ‘Off the Map: On Violence and Cartography', European Journal of Social Theory, 6(4), pp. 409-25.

Paprocki, Kasia \& Jason Cons (2014) 'Life in a Shrimp Zone: Aqua- and Other Cultures in Bangladesh's Coastal Landscape', Journal of Peasant Studies 41(6), pp. 1109-1130.

Raghavan, Srinath (2013) 1971: A Global History of the Creation of Bangladesh, Cambridge: Harvard University Press.

Ramachandran, Sujata (1999) 'Of Boundaries and Border Crossings: Undocumented Bangladeshi “Infiltrators' and the Hegemony of Hindu Nationalism in India', Interventions, 1(2), pp. 235-53.

Robinson, Cabeiri (2013) Body of Victim, Body of Warrior: Refugee Families and the Making of Kashmiri Jihadists, Berkeley: University of California Press.

Roy, Haimanti (2012) Partitioned Lives: Migrants, Refugees, Citizens in India and Pakistan, 1947-1965, Delhi: Oxford University Press.

Samaddar, Ranabir (1999) The Marginal Nation: Transborder Migration From Bangladesh to West Bengal , New Delhi: Sage Publications.

Sassen, Saskia (2013) ‘When Territory Deborders Territoriality’, Territory, Politics, Governance, 1(1), pp. 21-45.

Schmitt, Carl (1985) Political Theology: Four Chapters on the Concept of Sovereignty, Chicago: University of Chicago Press.

Shewly, Hosna (2013) 'Abandoned Spaces and Bare Life in the Enclaves of the India-Bangladesh Border', Political Geography, 32, pp. 23-31.

Sinha, Mrinalini (2013) 'Is “Region” Still Good to Think?', Comparative Studies of South Asia, Africa, and the Middle East, 33(3), pp. 264-67.

Stoler, Ann \& Frederick Cooper (1997) 'Between Metropole and Colony: Rethinking a Research Agenda', in Frederick Cooper and Ann Stoler (eds.), Tensions of Empire: Colonial Cultures in a Bourgeois World, Berkeley: University of California Press, pp. 1-57.

Sur, Malini (2012) 'Registers of Imprecision', The Telegraph, August 2, URL:http:// www.telegraphindia.com/1120802/jsp/opinion/story_15803324.jsp\#.UBph_mHYCSp.

Sur, Malini (2013) 'Through Metal Fences: Material Mobility and the Politics of Transnationality at Borders', Mobilities, 8(1), pp. 70-89. 
Sur, Malini (2014) 'Divided Bodies: Crossing the India-Bangladesh Border', Economic and Political Weekly, 44(13), pp. 31-5.

Swain, Ashok (1996) 'Displacing the Conflict: Environmental Destruction in Bangladesh and Ethnic Conflict in India', Journal of Peace Research, 33(2), pp. 189-204.

The Times of India (2013) 'Bangladesh land swap bill tabled in Rajya Sabha', December 19, URL: http://timesofindia.indiatimes.com/india/Bangladesh-land-swap-bill-tabled-in-Rajya-Sabha/ articleshow/27611996.cms.

Tsing, Anna (1993) In the Realm of the Diamond Queen: Marginality in an Out-of-the-Way Place, Princeton: Princeton University Press.

Van Schendel, Willem (2002a) 'Geographies of Knowing, Geographies of Ignorance: Jumping Scale in Southeast Asia', Environment and Planning D: Society and Space, 20, pp. 647-68.

Van Schendel, Willem (2002b) 'Stateless in South Asia: The Making of the India-Bangladesh Enclaves', The Journal of Asian Studies, 61(1), pp. 115-47.

Van Schendel, Willem (2005) The Bengal Borderland: Beyond State and Nation in South Asia, London: Anthem Press.

Whyte, Brendan (2002) Waiting for the Esquimo: An Historical and Documentary Study of the Cooch Behar Enclaves of India and Bangladesh, Melbourne: University of Melbourne School of Anthropology, Geography, and Environmental Studies.

Zaman, Sheik Shahariar (2014) 'BJP Strongly Opposes LBA with Bangladesh' Dhaka Tribune, February 25, URL: http://www.dhakatribune.com/foreign-affairs/2014/feb/25/bjp-stronglyopposes-lba-bangladesh.

Zamindar, Vazira Fazila-Yacoobali (2007) The Long Partition and the Making of Modern South Asia: Refugees, Boundaries, Histories, New York: Columbia.

\section{NOTES}

1. Thanks to Aminah Mohammad-Arif for inviting me to participate in this special issue and to Townsend Middleton and to three extremely thought provoking reviewers for comments on earlier versions of this paper. Funding for this project was generously provided by the Social Science Research Council's IDRF fellowship.

2. These enclaves are recognized by each state and regularly appear on maps of the region, however, they are inaccessible and unadministered by their 'home' state because they fall on the wrong side of an international boundary. The bill also makes provisions for the resolution of disputes over a series of spaces held in 'adverse possession' by both states, and several kilometers of undemarcated border.

3. The literature on this subject is vast. Texts addressing these issues specifically related to the India-Bangladesh border include Van Schendel (2002b, 2005), Hussain (2013), Jones (2009, 2012), Sur (2013), McDuie-Ra (2012), Roy (2012), Feldman (2003), and Chatterji (1999, 2007).

4. There is a robust debate in political geography on moving beyond the vision of states as naturalized containers of society. For a useful review of its various manifestations, see Brenner (1999).

5. Examples of dissonance between geographic imaginations and lived realities abound in South Asia, including the massive displacements of Partition (Zamindar 2007), disputes over territorial possession (Ibrahim 2009, Robinson 2013), struggles for regional autonomy and independence 
(Raghavan 2013, Middleton n.d.), questions about shared resources (Swain 1996), and the identities and locations of increasingly mobile populations (Samaddar 1999, Sur 2013).

6. I echo here classic claims of postcolonial scholarship that seek to bring the metropole and the colony into a single analytic frame (Stoler \& Cooper 1997).

7. See, for example, Garg (2013).

8. Though it assumes more significance when viewed against the backdrop of, for example, the BJP's recent call for Bangladesh to give land to India in compensation for the migration of Bangladeshis into Assam (BDnews24.com 2014). Here, fragmented territories are intimately indexed to broader meanings of population, demography, and possession, highlighting the ways that even tiny amounts of land are over-determined within nationalist logics of space.

9. Nehru's optimism seems, retrospectively, fantastic in the context of the range of seemingly intractable problems presented by the border in the post-Partition period. For an exploration of these, see Van Schendel (2005).

10. Billé goes so far as to suggest that lost territory is best understood as a 'phantom limb' in the national psyche.

11. Dahagram is approximately 4,600 acres in size.

12. I make no claim here that Dahagram is representative of all enclaves. Indeed, for reasons outlined above, it is quite distinct. For an exploration of the conditions of other chhitmahal, see Jones (2009) and Shewly (2013).

13. For a full discussion of all of these issues, see Cons (n.d).

14. Themselves industries deeply implicated in the contemporary production of territory in Bangladesh (see Paprocki \& Cons 2014).

15. A gesture, of course, with anticipated material benefits for all.

16. For more on the commodity flows-licit and illicit-across this border, see Sur (2013).

17. What the fate of Dahagram and the LBA will be under the new Modi administration is, as yet, unclear. However, the BJP has voiced opposition to any attempts to 'hurriedly' resolve border disputes through the LBA (Zaman 2014). Moreover, in the past, the BJP has regularly used the question of cross-border migration as an issue to consolidate political power (Ramachandran 1999).

18. See Tsing (1993) and essays in Das \& Poole (2004).

19. See Ludden (2003), Sur (2013), Samaddar (1999).

\section{ABSTRACTS}

This essay makes a case for reconceptualizing South Asia by refiguring postcolonial territory. It does this by bringing together the broad political history of a series of enclaves along the IndiaBangladesh border with an ethnographic discussion of the contemporary political economy of Dahagram, the largest of these enclaves. The essay argues for a need to bring nationalist framings of space and more textured explorations of everyday forms of territory-making into a single analytic frame. Doing so provides a way to understand and think beyond the territorial impasses posed by nationalist framings of space-the inability to disentangle lived realities from affectively charged conceptualizations of the nation and its borders. The essay, instead, reframes territory as the relationality between broad spatial imaginaries and lived realities at the margins. 
Such a view allows for a conceptualization of the region that builds upwards from quotidian negotiations to challenge nationalist and communal geographies.

INDEX

Keywords: India, Bangladesh, border, enclaves, territory, region

\section{AUTHOR}

\section{JASON CONS}

Research Assistant Professor, University of Texas, Austin 